\title{
Paramyotonia Congenita without Cold Paralysis
}

National Cancer Institute

\section{Source}

National Cancer Institute. Paramyotonia Congenita without Cold Paralysis. NCI

Thesaurus. Code C122794.

An autosomal dominant inherited non-dystrophic myotonia caused by mutations of the SCN4A gene. It is characterized by muscle stiffness, which is increased by exposure to cold but does not change to flaccid paralysis with intense cooling. 